\section{Energy Balance Relative to Percent Plant Cover in a Native Community ${ }^{1}$}

\section{J. KRISTIAN AASE AND J. ROSS WIGHT}

Research Soil Scientist and Range Scientist, Northern Plains Soil and Water Research Center, U.S. Department of Agriculture Sidney, Montana.

\section{Highlight}

Net radiation $\left(\boldsymbol{R}_{n}\right)$ and evapotranspiration $(E T)$ were poorly correlated during both a "wet" and a "dry" period on native range near Sidney, Montana within each of five levels of vegetational cover. The ratio $E T: R_{n}$ fluctuated greatly in all cases and was generally higher during the period of higher rainfall. During dry periods, substantial amounts of energy were dissipated as heat flux to the atmosphere. Maximum evaporation and/or transpiration from $0 \%, 25 \%, 50 \%, 75 \%$, and $100 \%$ cover occurred for 12 days after rainfall and was, respectively, $0.7,0.8,1.1$, 0.3 , and 1.9 times the evaporation from a Class $A$ evaporation pan. Total evapotranspiration for the season was $21 \%$ lower and dry matter production was $14 \%$ higher with $50 \%$ cover than with complete cover. Water use from $75 \%$ and $\mathbf{2 5} \%$ cover was similar to that from $\mathbf{5 0 \%}$ cover, but forage yields were $5 \%$ and $14 \%$ less, respectively, than from complete cover.

Understanding environment-vegetation relationships is necessary for development of sound range management practices. Little quantitative information is available relative to the relationship between native range grasses and environment-especially microenvironment. The partitioning of thermal energy received by native plant communities has received little attention.

Inadequate soil water limits production on western rangeland and great benefits can be realized from conservation practices that maximize wateruse efficiency of range plants. In the past, research has been directed towards increasing available water for plant use through such practices as range pitting, contour furrowing, and water spreading. Little attention has been given to what effect these practices have on partitioning the heat load and on water-use efficiency of plants. A better understanding of soil, plant, and meteorological factors that influence water use by plants is basic to development of methods for improving water-use efficiency (Staple, 1964).

Evapotranspiration from any crop under dry-

${ }^{1}$ Contribution from the Northern Plains Branch, Soil and Water Conservation Research Division, Agricultural Research Service, USDA, in cooperation with the Montana Agricultural Experiment Station, Journal Series No. 948. Received June 30, 1969; accepted for publication September 26,1969 . land or irrigated conditions can be estimated from the following equation

$$
E T=R_{n}-S-A
$$

where $E T$ is evapotranspiration, $R_{n}$ is net radiation, $S$ is sensible heat flux to the soil, and $A$ is sensible heat flux to the atmosphere. In humid rcgions or over well-watcred surfaces, $S$ and $A$ arc generally small and $E T$ is closely related to $R_{n}$. Under more arid climatic and dryland conditions, $S$ and $A$ become larger, and the close relationship of $E T$ to $R_{n}$ no longer exists. Under extremely dry conditions, as in desert areas, almost all net radiation $R_{n}$ will appear as sensible heat flux $A$ at some later time. The integrated value of $S$ (at least over 24-hour periods) is generally zero; i.e., what enters the soil by day, generally leaves by night (Penman et al., 1967). However, at Akron, Colorado, Hanks et al. (1968) found that $S$, averaged over 10-day periods during the 1966 and 1967 growing seasons, contributed an equivalent of 0.1 to $1.2 \mathrm{~mm} E T$ per day from native grass and up to $1.4 \mathrm{~mm} E T$ per day from oats and winter wheat.

The objectives of this study were to determine the energy balance of a native plant community and the relationship of plant cover to the microclimate in the semiarid northern Great Plains.

\section{Procedure}

The research area, located on approximately 12 ha of native rangeland about $3.2 \mathrm{~km}$ northwest of Sidney, Montana, is described as a sandy glaciated plains range site in a 25- to $36-\mathrm{cm}$ precipitation zone. Annual precipitation averages $33 \mathrm{~cm}$ with about $80 \%$ received during the growing season (April through September). The range was in good to fair condition according to the Soil Conservation Service range classification system. Vegetation is a blue gramathreadleaf sedge-needleandthread (Bouteloua-Carex-Stipa) faciation of the mixed prairie association (Weaver and Albertson, 1956). Basal cover, determined by the point method, was $13.1 \%$ and foliar density (counting all foliar hits) was about $23 \%$.

Five plots, each 6 by $15 \mathrm{~m}$, were located on fairly level land (less than $1 \%$ slope). Each plot was sectioned into 1-m-wide strips running the length of the plot. Part of each 1-m strip was tilled in September 1966 with a rotary tiller to create five crop levels: $0 \%$ (bare fallow), $25 \%, 50 \%$, $75 \%$, and $100 \%$ cover. The fallow strips were maintained weed free.

Evapotranspiration in cach plot was cvaluatcd by daily readings from hydraulic lysimeters (similar to those described by Hanks and Shawcroft, 1965). Daily evaporation was measured from a U.S. Weather Bureau Class A evaporation pan. Net radiometers of the type described by Fritschen (1965) were placed about $120 \mathrm{~cm}$ above the crop. Four heat flow discs (HF-1, manufactured by National Instruments Laboratories, Inc. ${ }^{2}$ ), connected in series, were placed about

\footnotetext{
${ }^{2}$ Company name is included for the benefit of the reader and does not imply any endorsement or preferential treatment by the U.S. Department of Agriculture of the product listed.
} 


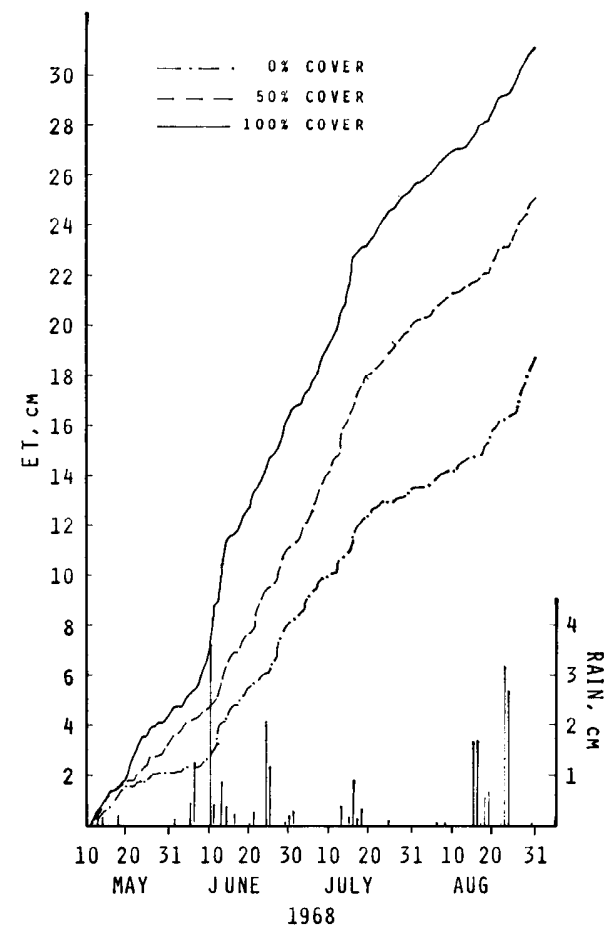

FIG. 1. Cumulative evapotranspiration (ET) and individual rains during the 1968 growing season.

$1 \mathrm{~cm}$ below the soil surface of each plot. The outputs from both the net radiometers and heat flow discs were recorded on an automatic data logging system throughout May and June. Sensible heat flux to the air was calculated from equation [1]. Total solar radiation was measured by a Kipp and Zoncn ${ }^{3}$ solarimeter and integrated over daily periods with an electronic integrator described by Hanks and Gardner (1968). All energy terms are expressed as equivalent centimeters of water per day, assuming that 1 $\mathrm{cm}$ of water is equivalent to $590 \mathrm{cal} / \mathrm{cm}^{2}$. Soil water was determined to a depth of $120 \mathrm{~cm}$ with a neutron probe.

Total dry matter yield for the growing season was estimated by clipping vegetation at ground level in two 0.5 by $2.0-\mathrm{m}$ sampling quadrats in each treatment. Water-use efficiency calculations were based on yields for entire plot areas.

\section{Results and Discussion}

Figure 1 shows cumulative water loss from three of the five treatments studied and the amounts of rain received at different times during the growing season. Water loss from the other two treatments, $25 \%$ and $75 \%$ cover, was similar to water loss from $50 \%$ cover. Evaporative loss of both precipitation and soil water was greater with full plant cover than with partial or no plant cover. In all cases, rate of water loss was greatest during and following periods of rainfall.

Precipitation exceeded evaporation from the allfallow plot by $5.6 \mathrm{~cm}$ from May 11 to August 31, with evaporation being most rapid after a rain.
Table 1. Dry matter production and water use on miniature fallow plots. Values are based on harvest date, 9 August 1968.

\begin{tabular}{rccc}
\hline \hline Cover & $\begin{array}{c}\text { Dry matter } \\
\left(\mathrm{g} / \mathbf{m}^{2}\right)\end{array}$ & $\begin{array}{c}\text { Water use } \\
(\mathrm{cm})\end{array}$ & $\begin{array}{c}\text { Water-use } \\
\text { efficiency } \\
\left(\mathrm{g} / \mathbf{m}^{2} / \mathbf{c m}^{1}\right)\end{array}$ \\
\hline $0 \%$ cover & - & 14.2 & - \\
$25 \%$ cover & 62.9 & 19.0 & 3.31 \\
$50 \%$ cover & 84.1 & 21.2 & 3.97 \\
$75 \%$ cover & 70.1 & 19.9 & 3.52 \\
$100 \%$ cover & 73.6 & 26.9 & 2.73 \\
\hline
\end{tabular}

Total precipitation for the period was $24.2 \mathrm{~cm}$. Assuming no runoff, fallow storage efficiency (5.6/ $24.2 \times 100$ ) was $23.1 \%$. Evapotranspiration was highest from complete cover, with $31.1 \mathrm{~cm}$ of water lost. This quantity exceeded rainfall by $6.9 \mathrm{~cm}$ during the period. $E T$ from $25 \%, 50 \%$, and $75 \%$ cover was 0.5 and $0.8 \mathrm{~cm}$ higher, and $0.2 \mathrm{~cm}$ lower, respectively, than the rainfall received. No attempt was made to separate effects of individual species on measured parameters.

Total forage production from the plots and water loss from lysimeters are summarized in Table 1 for the preharvest period. The $50 \%$-cover treatment produced the most vegetation and used water most efficiently. Complete cover was second highest in yield but lowest in water-use efficicncy. The data suggest that partial manipulation of plant cover may result in higher production and more efficient water use on rangeland than does full cover.

Pan evaporation is an integrator of all climatic factors affecting evapotranspiration. The ratios of evapotranspiration to evaporation for a U.S. Weather Bureau Class A evaporation pan, determined for all treatments, are plotted in Figure 2. During the frequent and relatively heavy rains the first half of June-when soil water content was highest-complete cover used nearly twice as much water as $50 \%$ cover, which in turn used more water than $25 \%$ cover. Fallow lost slightly less water than $25 \%$ cover. The reason for the anomalous behavior of the plot with $75 \%$ cover is unknown. The only time any of the treatments exceeded an $E T: E_{p a n}$ ratio of one was during the rainy, vigorous plantgrowth period in June. Nearly $6 \mathrm{~cm}$ of rain the third week of August was reflected by increased $E T / E_{p a n}$. Transpiration increased as a result of initiation and growth of new tillers. Pan evaporation appears to be a poor estimator of $E T$ from rangeland in this climatic region.

Radiation measurements were taken during a comparatively dry period in May, and, for contrast, immediately after heavy rainfall in June. Table 2 shows daily averages for the periods in- 


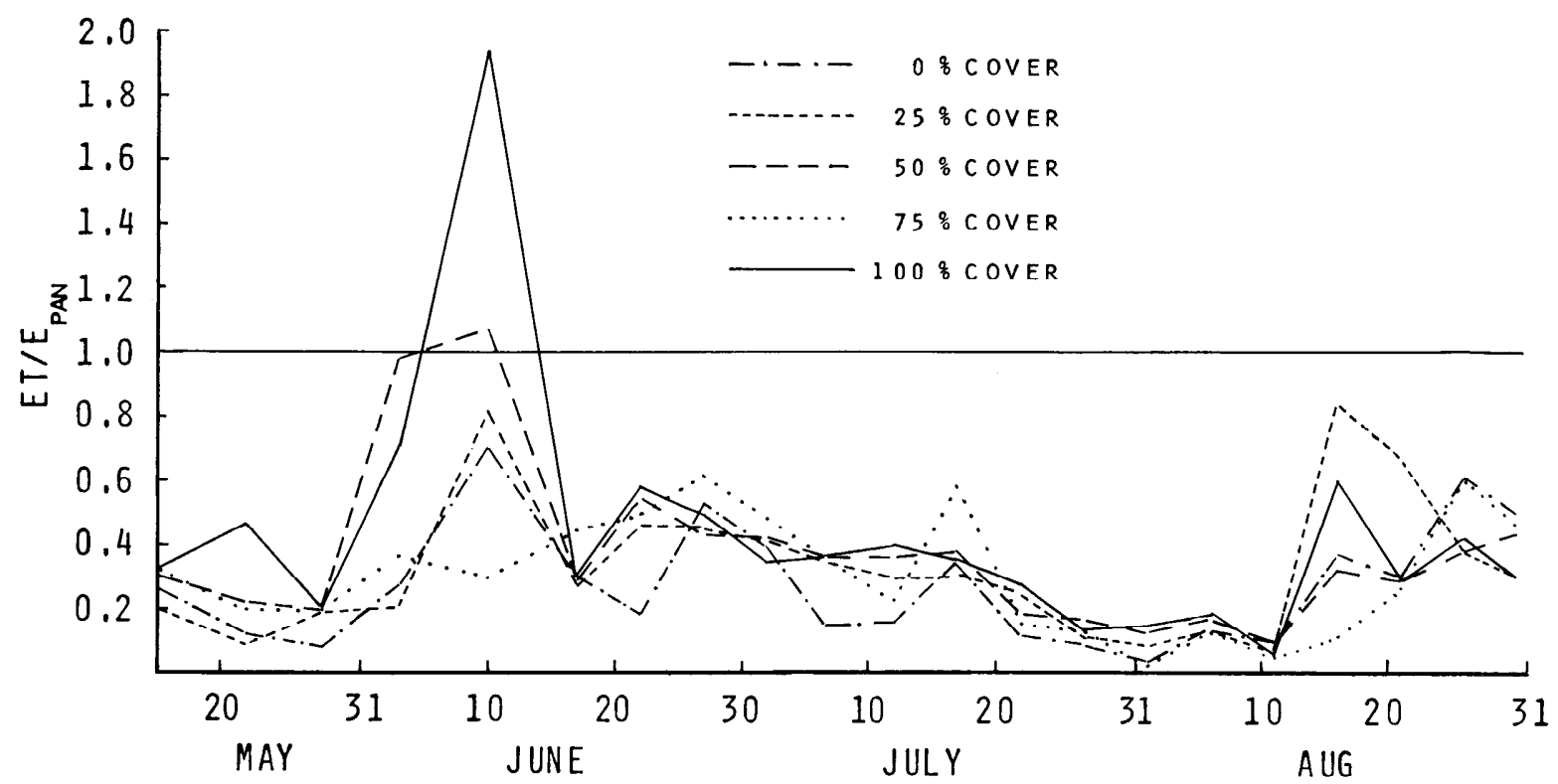

1968

Fig. 2. Ratio of evapotranspiration $E T$ to evaporation from Class A Weather Bureau evaporation pan $E_{p a n}$, based on 5 -day averages for the period 15 May to 30 August 1968.

dicated. The ratios of net radiation $R_{n}$ to total solar radiation $R_{t}\left(R_{n} / R_{t}\right)$ were higher during the "wet" period than during the "dry" period. This ratio depends on characteristics of crop and soil surfaces. The ratios ranged from 0.5 during the "dry" period to 0.7 during the "wet" period, sug-

Table 2. Total rainfall $\left(\boldsymbol{P}_{t}\right)$, total radiation $\left(\boldsymbol{R}_{t}\right)$, net radiation $\left(R_{n}\right)$, sensible heat flux to the soil $(S)$, evapotranspiration $(E T)$, and sensible heat flux to the $\operatorname{air}(A)$ for two periods in 1968 for five levels of plant cover on native range near Sidney, Montana. Values are given as equivalent centimeters of water per day and are averaged over the two periods, respectively.

\begin{tabular}{rccccccccc}
\hline \hline Plant Cover & $P_{t}$ & $R_{t}$ & $R_{n}$ & $R_{n} / R_{t}$ & $S$ & $E T$ & $E T / R_{n}$ & $A$ \\
\hline \multicolumn{7}{c}{24} & \multicolumn{1}{c}{ May-1 June (dry) } \\
$0 \%$ cover & .011 & 1.03 & .54 & .54 & .04 & .15 & .28 & .35 \\
$25 \%$ cover & .011 & 1.03 & .54 & .54 & .04 & .16 & .30 & .34 \\
$50 \%$ cover & .011 & 1.03 & .51 & .50 & .04 & .19 & .37 & .28 \\
$75 \%$ cover & .011 & 1.03 & .55 & .53 & .03 & .16 & .29 & .36 \\
$100 \%$ cover & .011 & 1.03 & .57 & .55 & .05 & .18 & .32 & .34 \\
& 13 & June-24 June (wet) & & & \\
$0 \%$ cover & $.314^{*}$ & .69 & .42 & .61 & .02 & .18 & .43 & .22 \\
$25 \%$ cover & $.314^{*}$ & .69 & .45 & .65 & .02 & .28 & .62 & .15 \\
$50 \%$ cover & $.314^{*}$ & .69 & .45 & .65 & .02 & .39 & .87 & .04 \\
$75 \%$ cover & $.314^{*}$ & .69 & .48 & .70 & .02 & .25 & .52 & .21 \\
$100 \%$ cover & $.314^{*}$ & .69 & .48 & .70 & .02 & .39 & .81 & .07 \\
\hline
\end{tabular}

* A total of $3.94 \mathrm{~cm}$ of rain fell during the three days prior to 13 June. gesting that the crop absorbed a greater proportion of the solar radiation during times of low insolation. Tanner and Lemon (1962) cited $R_{n}: R_{t}$ ratios of about 0.5 at three locations in the Midwest and of 0.65 to 0.70 in Hawaii, and Grable et al. (1966) found ratios of 0.6 to 0.9 for wet mountain meadows in Colorado. The $50 \%$ cover seemed to absorb solar radiation morc efficicntly than fallow and $25 \%$ cover during the "wet" period.

On all treatments, net radiation consistently exceeded evapotranspiration. From June 13 to June $24, E T$ on $50 \%$ and $100 \%$ cover approached $R_{n}$, with $E T / R_{n}$ being 0.87 and 0.81 , respectively. In all cases, even though both $R_{t}$ and $R_{n}$ were lower, ET was higher in June than in May. This was a reflection of the higher rainfall in Junemore water was available for transpiration and evaporation. Inadequate soil water limited plant growth in May. The rains in June sharply increased growth rates.

Daily $E T: R_{n}$ ratios are plotted in Figure 3. There was a marked increase in daily $E T / R_{n}$ during the rainier period, with all treatments except fallow exceeding or equaling unity at least once.

A large part of the net radiation received is dissipated as sensible heat to the air during dry periods (Table 2). During wet periods, most of the net radiation is dissipated as evaporation. During the periods of measurement, sensible heat flux to the atmosphere $A$ was positive, indicating that the air above the plots was being heated. Sensible heat exchange with the air was less during the rainier period, as expected.

The data in Table 2 show that $50 \%$ cover had the 


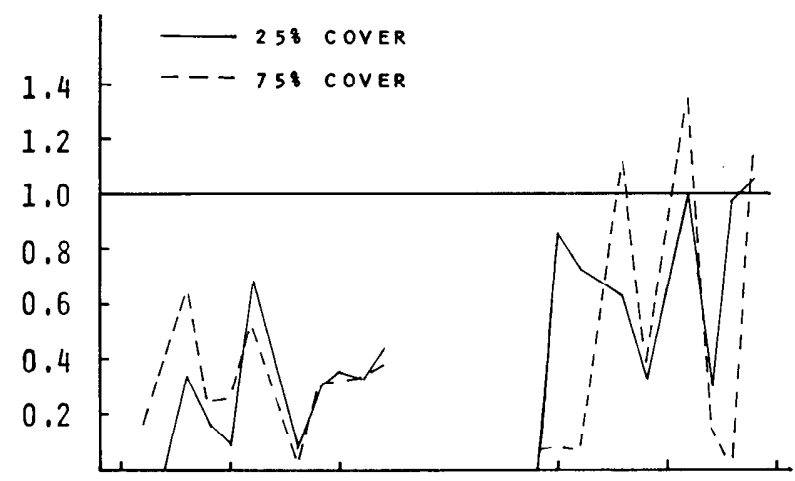

highest evaporation rate of any treatment in the measured dry and wet periods; however, this was true only for these periods. For the entire season, complete cover used the most water (Fig. 1). The data in Figure 1 show that percentage cover does have a real effect on water use.

\section{Literature Cited}

Fritschen, L. J. 1965. Miniature net radiometer improvements. J. Appl. Meteor. 4:528-532.

Grable, A. R., R. J. Hanks, F. M. Willhite, and H. R. HAISE. 1966. Influence of fertilization and altitude on energy budgets for native meadows. Agron. J. 58:234-237.

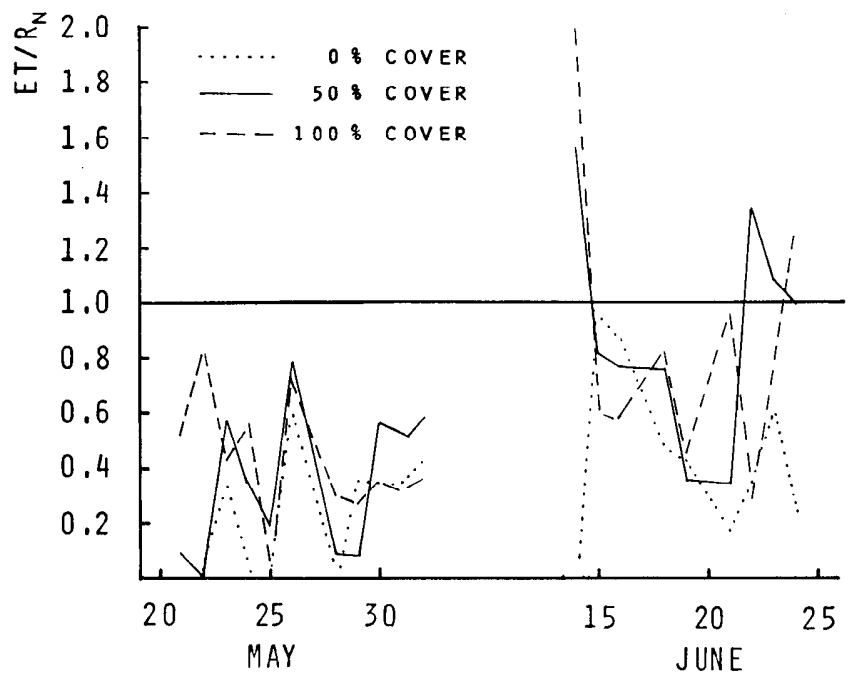

FIG. 3. Ratio of evapotranspiration to net radiation during a "dry" period (21 May-1 June) and a "wet" period (14 June24 June) in 1968.

Hanks, R. J., and H. R. Gardner. 1968. Portable counting integrator for low-voltage signals. U.S. Dep. Agr. ARS 41-139.

Hanks, R. J., H. R. Gardner, and R. L. Florian. 1968. Evapotranspiration-climate relations for several crops in the central Great Plains. Agron. J. 60:538-542.

Hanks, R. J., and R. W. Shawcroft. 1965. An economical lysimeter for evapotranspiration studies. Agron. J. 57: 634-636.

Penman, H. L., D. E. Angus, and G. H. M. van Bavel. 1967. Microclimatic factors affecting evaporation and transpiration, chapter 26. In Irrigation of agricultural lands, ASA Pub. No. 11, Madison, Wisconsin.

Staple, W. J. 1964. Dryland agriculture and water conservation, p. 15-30. In Research on water, ASA Spec. Pub. No. 4, Soil Sci. Soc. Amer., Madison, Wisconsin.

Tanner, C. B., And E. R. Lemon. 1962. Radiant energy utilized in evapotranspiration. Agron. J. 54:207-212.

Weaver, J. E., and F. W. Albertson. 1956. Grasslands of the Great Plains-their nature and use. Johnsen Pub. Co., Lincoln, Nebraska. 395 p.

\section{THESIS: UNIVERSITY OF NEVADA}

\section{Replacing Shadscale Range with Perennial Grasses and Trends of Crested Wheatgrass Seedings in Northern Nevada, by Allen D. Bruner. M.S. 1967.}

Revegetation of shadscale with perennial grasses in an 8 inch annual precipitation zone was attempted for 3 years. Seedbed preparation included plowing, plowing plus nitrogen fertilizer, shredding (brush beating), shredding plus mulch, root-planning, pitting, and spraying. Species seeded were pubesccnt, bcardlcss, and standard crested wheatgrass and Russian wildrye.

Grass establishment was very light. Russian wildrye survived best. All treatments were rated failure after four years. Downy brome, an understory prior to treatment, became the major invader. It became most prevalent on treatments which disturbed soil the least, such as shredding, and less prevalent on plowing and root-planning. Halogeton and Russian thistle responded conversely. These species increased for two years following treatments, then declined sharply.
Vegetation trend was measured on 14 crested wheatgrass seedings in northern Nevada for eight years 1955 to 63). Crested wheatgrass exhibited an upward trend in 11 seedings. The increase ranged from slight to prodigious. Three seedings maintained a downward trend. One of these was rated as a failure the first year after seeding; the other two were rated fair. All seedings rated good or excellent three years after seeding had upward trends in crested wheatgrass. Halogeton showed the same general upward trend in 13 seedings. Increases were negligible in those seedings with strong upward trends in crested wheatgrass. Big sagebrush increased slightly in all seedings.

Median grazing intensity ranged from 1.3 acres/AUM to 7.6 acres/AUM. Under these varying intensities, seedings maintained an upward trend and were not abused. 